\title{
Salinity Stress Responses in Some Grape Rootstocks.
}

\author{
${ }^{*}$ Abdrabboh, G.A., ${ }^{1}$ Abdel Aziz, H. F., ${ }^{2}$ El-Boghdady, A., and ${ }^{3}$ Ismail, A. \\ ${ }^{1}$ Department of Horticulture, Faculty of Agriculture, Al-Azhar University, Nasr city, Cairo, Egypt. \\ ${ }^{2}$ Horticulture Research Institute, Agricultural Research Center, Giza, Egypt. \\ ${ }^{3}$ Department of Biotechnology, Faculty of Agriculture, Al-Azhar University, Nasr city, Cairo, Egypt. \\ Corresponding author: hosny_fathy86@azhar.edu.eg
}

\begin{abstract}
The study was conducted between 2014 and 2016 to monitor the effect of high level concentrations of $\mathrm{NaCl}$ on the micropropagation of some grape rootstocks Salt creek, Dog ridge, Richter and Freedom. The genetic analysis of molecular markers was performed using five primers of Inter Simple Sequence Repeat (ISSR). The five ISSR primers produced a total number of amplified bands ranged from 2 to 7 fragments. The highest number of fragments was 7 bands for 17898-B primer. While HB-15 primer generated the lowest number of amplicons (2 bands). The percentage of polymorphism revealed by the different primers ranged from 33.33 to $83.33 \%$ with an average of $54.29 \%$. In our analysis we were able to identify and evaluate the grape genetic diversity and to study the phylogenetic relationships between cultivars. Also, the soluble proteins of leaves from four tested grape rootstocks were separated by slab gel electrophoresis into 12 protein bands, but only 2 to 5 bands were found in each cultivar. The peroxidase patterns exhibited a total number of 7 bands in each cultivar three of them were monomorphic bands $(\mathrm{Rf}=0.077-0.138-0.757)$ in rootstock and under salinity stress. The generic variations detected among closely related genotypes indicate the efficiency of protein and isozyme markers for evaluating and constructing genetic linkage maps and the biochemical genetic diversity of these cultivars.
\end{abstract}

Keywords: Salinity Stress, Grape Rootstocks, ISSR, $\mathrm{NaCl}$

\section{Introduction}

Grapevine (Vitis vinifera L.) is one of the major perennial fruit crops and a member of the family of Vitaceae and is divided into 12 genera. Vitis vinifera is the most widely cultivated species of the genus Vitis and is grown throughout the temperate and tropical regions. Vitis vinifera is known for its wide morphological and genetic diversity with a large number of cultivars Teixeira et al., (2013) Despite the botanical homogeneity, grape varieties possess a wide and unique phenotypic variability regarding berries size, shape, colour, and quality traits including berry composition, the content of sugars, acidity and organic acids Shiraishi et al., ( 2009). The cultivars characterization is an essential stage in the certification program, improvement and conservation of germplasm, and monitoring the genetic quality Johnson and Hodgkin, (1999). Morphological and microsatellites analysis were the most useful techniques in the differentiation of the studied cultivars and accessions, though the latter one was definitive for the correct identification of cultivars Neveen et al., (2011). PCR based DNA markers, provide a powerful tool for genetic analysis because of their simplicity and ease of handling. Inter-Simple Sequence Repeat Polymorphic DNA (ISSR) is a fast technique for generating genetic markers Zietkiewicz et al., (1994). ISSR are applied to many aspects of genetic research such as cultivar identification Goulão \& Oliveira, (2001) and Monte-Corvo et al., (2001) determination of genetic relationship Potter $\boldsymbol{e t}$ al., (2002), analysis of genetic diversity, construction of linkage genetic maps and others Roose et al., (2000) and Sankar\& Moore (2001). In grapes, ISSR approach has been applied so far to analyze the limited number of varieties Moreno et al., (1998) and Herrera et al., (2002).Several manuscripts reported the usefulness of using ISSR for cultivar identifications. The ISSR as markers to plant genetics technique isn't much more difficult than RAPD (Random Amplification of Polymorphic DNA) requiring a small amount of DNA for amplification and enabling the detection of the genome Zietkiewicz et al., (1994). ISSRs are ideal as markers for genetic mapping and population studies because of their abundance and the high degree of polymorphism between individuals within a population of closely related genotypes Lanham, \& Brennan, (1998). Because of the protein profile high stability, protein electrophoresis became a powerful tool in revealing the origin and the evolution of cultivated plants, as isozyme analysis has been used to differentiate between closely related cultivars and to identify differentially regulated genes in different organs of the same plant Ben-Hayyim et al., (1982). Therefore, isoenzyme pattern analysis by gel electrophoresis has been used in higher plants to study various problems in breeding, genetics, and taxonomy El-Sharabasy et al., (2008) and Khan et al., (2010). The phylogenetic analyses were used to study the genetic relatedness between and among cultivars Khan et al., (2010). So, the objective of this experiment was to use the phylogenetic analysis to study the genetic relatedness among grape rootstocks exposed to high salt stress.

\section{Materials and Methods}

This analysis was carried out during the period of 2014 to 2016 to study the effect of high level $\mathrm{NaCl}$ on 
four micropropagated grape rootstocks were cultured in the greenhouse of the Department of Horticulture Faculty of Agriculture - Al-Azhar University in Cairo such as Salt Creek, Dog ridge, Richter, and Freedom. Current shoots of four grape rootstocks namely Salt Creek, Freedom, Dog ridge and Richter were excised from 3- year- old plants. Shoots were primarily cleaned under running tap water for $30 \mathrm{~min}$ to eliminate dust then immersed in $70 \%$ ethanol solution for $30 \mathrm{~s}$, then sterilized by $2 \%$ sodium hypochlorite with droplets of tween 20 for 15 min. Explants were then rinsed three times with sterile distilled water and shortened to be $3-8 \mathrm{~mm}$ in length extra and then cultured on jars containing $25 \mathrm{ml}$ of half-strength Murashige and Skoog- (MS) basal medium supplemented with $30 \mathrm{~g} / \mathrm{L}$ sucrose, $7 \mathrm{~g} / \mathrm{L}$, agar, 1.0 $\mathrm{mg} / \mathrm{L} \mathrm{BA}$ and $0.01 \mathrm{mg} / \mathrm{L}$ NAA. Cultures were incubated at $27 \pm 2{ }^{\circ} \mathrm{C}$ with a $16 \mathrm{~h}$ photoperiod. After 30 days, uniform developed explants were excised and recultured on the same medium to elongate them. Micro-shoots of all tested grape rootstocks were transferred to the MS media supplemented with sodium chloride $(\mathrm{NaCl})$ at 0.0 and $100 \mathrm{mM}$. After 30 days, the following molecular characteristics were done:

\section{Molecular Markers}

Isolation and quantification of DNA:

DNA extraction was carried out using leaf material collected from each cultivar. Genomic DNA was extracted and purified using the DNeasy Plant Mini Kit and following the manual instructions (QIAGEN, Chatsworth, CA).

\section{Scoring of Data:}

Scoring of ISSR data was performed using $2 \%$ agarose gel electrophoresis profile, as clear and distinct fragment were scored as (1) for the presence and $(0)$ for the absence.

\section{Inter Simple Sequence Repeats (ISSRs)-PCR:}

ISSR technique was performed in a total volume of $50 \mu \mathrm{l}$ containing $5 \mu \mathrm{l}$ of $10 \mathrm{x}$ buffer, $10 \mu \mathrm{l} \mathrm{Q}$ solution, $5 \mu \mathrm{l}$ of $2 \mathrm{mM}$ dNTPs, $80 \mathrm{pmol}$ of each primer, $0.5 \mu 1$ hot start Taq polymerase and 25ng DNA [4]. The temperature profile composed of initial denaturation cycle at $95^{\circ} \mathrm{C}$ for $2.5 \mathrm{~min}$ followed by 10 touchdown cycles of $95^{\circ} \mathrm{C} / 30 \mathrm{sec}, 65-55^{\circ} \mathrm{C} / 1 \mathrm{~min}$, $72^{\circ} \mathrm{C} 90 \mathrm{sec}$. This was followed by 30 cycles of $95^{\circ} \mathrm{C} /$ $0 \mathrm{sec}, 55^{\circ} \mathrm{C} / 1 \mathrm{~min}, 72^{\circ} \mathrm{C} / 90 \mathrm{sec}$ and then a final extension cycle at $72^{\circ} \mathrm{C}$ for $7 \mathrm{~min}$. The sequences of the five ISSR primers (844-B, 17898-A, 17898-B, HB-12 and HB-15) are presented in Table (1).

Table 1. Name and sequence of the primers used in ISSR analysis.

\begin{tabular}{ll}
\hline Primer Name & Sequence 3'-5' Anchored repeats \\
\hline $844-\mathrm{B}$ & $(\mathrm{CT})_{8} \mathrm{GC}$ \\
\hline $17898-\mathrm{A}$ & $(\mathrm{CA})_{6} \mathrm{AC}$ \\
\hline $17898-\mathrm{B}$ & $(\mathrm{CA})_{6} \mathrm{GT}$ \\
\hline $\mathrm{HB}-12$ & $(\mathrm{CAC})_{3} \mathrm{GC}$ \\
\hline HB-15 & $(\mathrm{GTG})_{3} \mathrm{GC}$ \\
\hline
\end{tabular}

\section{Biochemical and Genetic parameters Protein electrophoresis:}

A sample of $0.2 \mathrm{~g}$ of young fresh leaves was homogenized with $0.9 \mathrm{ml}$ of extraction buffer $(10 \mathrm{ml}$ $0.5 \mathrm{M}$ Tris pH6.8, $16 \mathrm{ml} 10 \% \mathrm{SDS}$, and 30ml D.W.). The extracts were transferred into Eppendorf tubes and centrifuged for $10 \mathrm{~min}$ at $10000 \mathrm{rpm}$ under cooling $\left(4^{\circ} \mathrm{c}\right)$. Supernatants (containing protein extract) were transferred into clean tubes and used for SDS-PAGE analysis. Isozymes were extracted (Jonathan and Weeden et al 1990). A volume of $120 \mu \mathrm{l}$ of protein extract was loaded into sodium dodecyl sulfate polyacrylamide gel (SDS-PAGE). $12 \% \mathrm{~W} / \mathrm{V}$ vertical slab using BIORAD Techware $1.5 \mathrm{~mm}$ according to the method of Laemmli, (1970) and modified by Studier, (1973). The molecular weights of proteins were estimated relative to a standard protein marker with a wide range of molecular weight (fermentas.com).

\section{Isozymes electrophoresis:}

Native - polyacrylamide gel electrophoresis (Native-PAGE) was conducted to identify isozyme variations among the four cultivars using one isozyme system using $12 \%$ (W/V) slab gel according to Stegmann Stegemann et al ., (1986). Isozymes were extracted from $0.2 \mathrm{~g}$ of fresh leaves in $1 \mathrm{ml}$ of $0.125 \mathrm{M}$ Tris-borate buffer, and pH8.9. A volume of $50 \mu 1$ extract of each sample was mixed with $12.5 \mu$ of glycerol, and $60 \mu \mathrm{l}$ from this mixture was applied to each gel well.

\section{Peroxidase Detection:}

Peroxidase was detected by incubating the gel in darkness for one hour at $37^{\circ} \mathrm{c}$ in a mixture of $15 \mathrm{ml}$ of $10 \%$ benzidine (in $95 \%$ ethanol), $50 \mathrm{ml}$ of $1 \mathrm{Mm}$ potassium acetate, and $1 \mathrm{ml}$ of $1 \% \mathrm{H} 2 \mathrm{O} 2$ ( $\mathrm{Ph} \mathrm{4.7).}$ After the incubation, the gel was rinsed in distilled water and fixed in 50\% glycerol for one hour. The gel was placed into this solution and 5 drops of hydrogen peroxide solution were added. The gel was incubated at room temperature until bands appeared Brown, (1978).

\section{Data Analysis:}

The banding patterns generated by ISSR primers were analyzed and compared to determine the genetic relatedness among different grapes accessions. The amplified fragments were scored either as present (1) or absent (0). The genetic similarity and similarity matrix were estimated according to Dice coefficient Sokal, (1963). The unweighted Pair Group Method 
with Arithmetic Averages (UPGMA) was used to construct the genetic relationships using Phoretix 1D software (Total Lab, UK).

\section{Results and Discussion}

The preliminary screening of the five ISSR primers (844-B, 17898-A, 17898-B, HB-12 and HB15) produced polymorphic amplification pattern (Fig.1), which were finally selected for molecular profiling of the grape varieties. The total number of amplified amplicons among tested primers ranged from 2 to 7 fragments. 3'anchored (CA)6GT primer amplified the highest number of fragments (7 bands). However, (GTG)3GC primer generated the lowest number of amplicons ( 2 bands). The average number of fragments/primer was (4.2) and the approximate size of these fragments ranged from 203.67 to 701.34 bps. All five primers formed polymorphic bands (Table 2) of the total of 21 scorable fragments, 13 of the accessions were polymorphic. The number of polymorphic bands varied between 1 and 5 producing an average of (2.6) of polymorphism/primer.

Table 2. Statistics of the ISSR fragments for the three grape cultivars (Vitis vinifera L.) based on the ten ISSR primers

\begin{tabular}{lcccc}
\hline $\begin{array}{c}\text { AF ISSR } \\
\text { primers }\end{array}$ & $\begin{array}{c}\text { Total amplified } \\
\text { fragments }\end{array}$ & monomorphic & $\begin{array}{c}\text { Polymorphic } \\
\text { fragments }\end{array}$ & $\begin{array}{c}\text { Polymorphism } \\
\boldsymbol{\%}\end{array}$ \\
\hline $844-\mathrm{B}$ & 3 & 2 & 1 & $33.333 \%$ \\
\hline $17898-\mathrm{A}$ & 6 & 1 & 5 & $83.333 \%$ \\
\hline $17898-\mathrm{B}$ & 7 & 2 & 5 & $71.429 \%$ \\
\hline HB-12 & 3 & 2 & 1 & $33.333 \%$ \\
\hline HB-15 & 2 & 1 & 1 & $50 \%$ \\
\hline Total & 21 & 8 & 13 & $\ldots .$. \\
\hline Average & 4.2 & 1.6 & 2.6 & $54.285 \%$ \\
\hline
\end{tabular}

The percentage of polymorphism revealed by different primers ranged from 33.333 to $83.333 \%$ with an average of $54.285 \%$. Earlier findings in grapevine cultivars also suggest wide variation in allele produced per primer such allelic variation may be due to the difference among the cultivars or varieties used
Seyedimoradi et al., (2012). ISSR analysis was used for the DNA profiling and characterization of total 143 Indian Grape varieties and rootstocks Tamhankar et al., (2008). Genetic relationships were detected among the 15 cultivars of Vitas spp. materials using ISSRs markers Wu et al ., (2009).

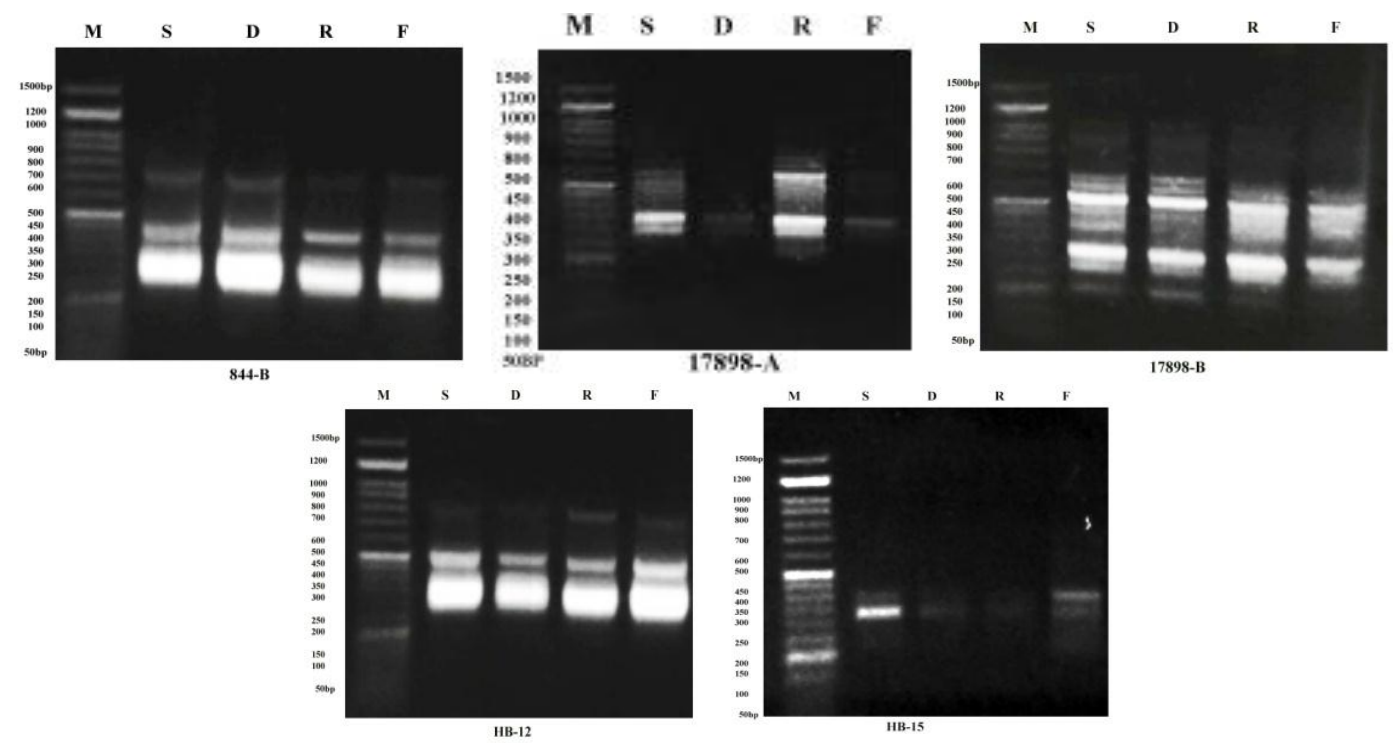

Fig. 1: ISSR profiles as detected by different ISSR primers for four Grape cultivars $\mathrm{M}=50 \mathrm{bp}$ marker (GeneDireX cat\# PM001-0500), $\mathrm{S}=$ Salt creek, $\mathrm{D}=\mathrm{Dog}$ ridge, $\mathrm{R}=$ Richter and $\mathrm{F}=\mathrm{Freedome}$.

\section{Cluster Analysis as Revealed by ISSR:}

The genetic relationship between the examined four cultivars of Vitis vinifera $L$. is illustrated in dendrogram using the linkage between varieties showing that the grape cultivars grouped into two major clusters (Fig. 2). It is clear that the two varieties Salt creek and Dog ridge are closer related than the
Richter. The highest value for similarity index was obtained for Salt creek with Dog ridge (0.96), and least similarity coefficient values obtained for Freedom- with Richter (0.36). Similar results were obtained among cultivars of V.vinifera by Alizadeh and Singh, (2009) and Zeinali et al ., (2012). 


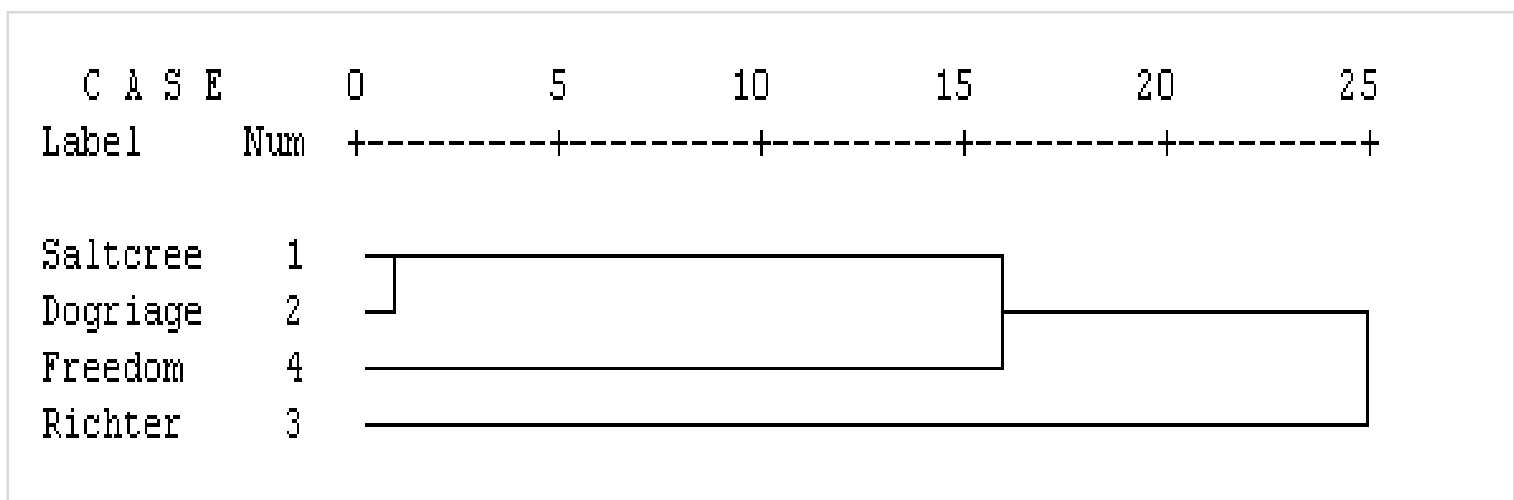

Fig. 2: Dendrogram showing the genetic relationships among the four grape cultivars (Vitis vinifera L.) based on the analysis of ISSR data.

Molecular markers are scattered throughout the genome and their association with various agronomic traits are influenced by the cultivator under selected stress induced by domestication. Interrelationships between grapes varieties are not very clear and more studies on morphological and agronomic traits and analysis of the clones with more number of reliable DNA markers like SSR, SNP may be helpful in confirming the results. Knowledge of the degree of genetic relationship between these varieties will be important for the germplasm collection, in situ conservation and Vitis breeding programs. The results of the present study will be useful in DNA fingerprinting and in determining the genetic diversity of the grapes.

\section{Biochemical and genetic identification:}

The protein banding profile which was separated using SDS-PAGE of the four tested grape rootstocks grown on $100 \mathrm{mM} \mathrm{NaCl}$ is illustrated in (Fig.3). The total number of bands were 12 bands with molecular weights ranged from 24.3 KDa to 83.5 KDa (Table 3). The highest 9 bands were detected in the Freedom grape rootstock when cultured on MS media complemented with $\mathrm{NaCl}$ at $100 \mathrm{mM}$, while the lowest 3 bands were identified in the two tested grape rootstocks Dogridge and Richter. Demonstrative analysis of the presence and absence of bands were assessed with (1) and (0), respectively, are illustrated in (Table 3). Two monomorphic bands (44.036 and $24.368 \mathrm{KDa}$ ) were observed, while 5 bands were polymorphic, giving $83.333 \%$ polymorphism and 5 unique bands.

Table 3. Data matrix illustrating the presence or absence of bands in the leaves protein electrophoresis banding patterns for Salt creek, Dogridge, Richter and Freedom grape rootstocks.

\begin{tabular}{|c|c|c|c|c|c|c|c|c|c|}
\hline \multirow{2}{*}{$\begin{array}{l}\text { Band } \\
\text { number }\end{array}$} & \multirow{2}{*}{ MW } & \multicolumn{2}{|c|}{ Salt creek } & \multicolumn{2}{|c|}{ Dogridge } & \multicolumn{2}{|c|}{ Richter } & \multicolumn{2}{|c|}{ Freedom } \\
\hline & & Control & Treated & Control & Treated & Control & Treated & Control & Treated \\
\hline 1 & 83.556 & 0 & 0 & 1 & 0 & 1 & 0 & 1 & 0 \\
\hline 2 & 77.776 & 0 & 1 & 0 & 1 & 0 & 1 & 0 & 1 \\
\hline 3 & 55.524 & 0 & 0 & 0 & 0 & 0 & 0 & 0 & 1 \\
\hline 4 & 51.447 & 0 & 0 & 0 & 1 & 0 & 0 & 0 & 0 \\
\hline 5 & 51.369 & 1 & 1 & 0 & 0 & 0 & 0 & 0 & 1 \\
\hline 6 & 49.447 & 0 & 0 & 0 & 0 & 0 & 0 & 1 & 0 \\
\hline 7 & 47.236 & 0 & 0 & 0 & 0 & 0 & 0 & 0 & 1 \\
\hline 8 & 44.036 & 1 & 1 & 1 & 1 & 1 & 1 & 1 & 1 \\
\hline 9 & 37.178 & 1 & 1 & 0 & 0 & 0 & 0 & 1 & 1 \\
\hline 10 & 33.312 & 1 & 1 & 0 & 0 & 0 & 0 & 1 & 1 \\
\hline 11 & 26.541 & 0 & 0 & 0 & 0 & 0 & 0 & 0 & 1 \\
\hline 12 & 24.368 & 1 & 1 & 1 & 1 & 1 & 1 & 1 & 1 \\
\hline \multicolumn{2}{|c|}{ Total } & 5 & 6 & 3 & 4 & 3 & 3 & 6 & 9 \\
\hline \multicolumn{2}{|c|}{ Polymorphism\% } & \multicolumn{8}{|c|}{$83.333 \%$} \\
\hline
\end{tabular}

M.W= Molecular weights $1=$ Present $\quad 0=$ Absent 
As shown in table 3, The results indicated that there was one protein band at $(83.556 \mathrm{KDa})$ existed in the control and absent in the treated Dogridge, Richter, and Freedom rootstocks, while there was one band at $(77.776 \mathrm{KDa})$ found in the four treated rootstocks and not found in their control.

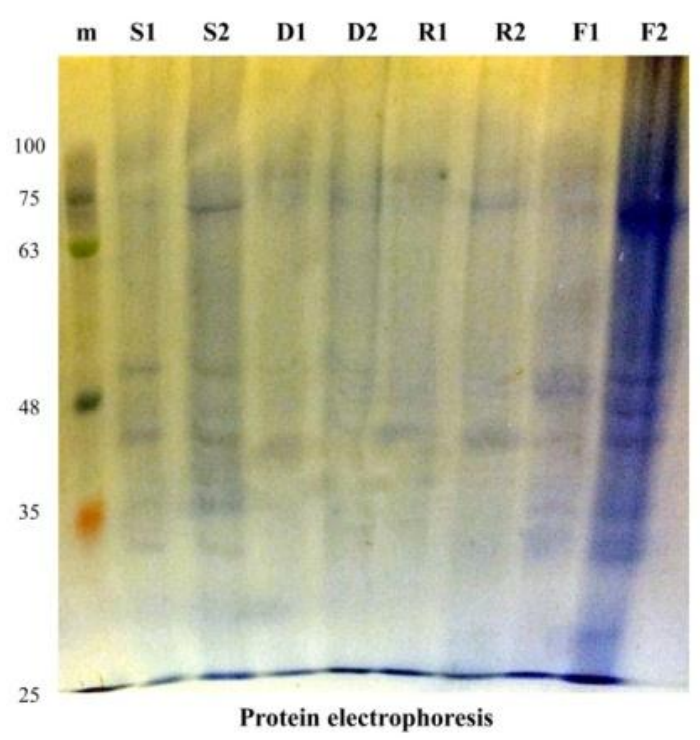

Fig (3): SDS-PAGE protein band in patterns of leaves of Salt creek, Dogridge, Richter and Freedom Rootstocks (M $=$ standard protein marker, $\mathrm{S}=$ Salt creek, $\mathrm{D}=$ Dogridge, $\mathrm{R}=$ Richter, and $\mathrm{F}=$ Freedome).

$1=$ rootstock control, $2=$ treatment $100 \mathrm{mM} \mathrm{NaCL}$.
On the other hand, one specific band was represented in salinity stress treatments at (51.447 KDa) in Dogridge grape tested rootstocks. The results indicated that two protein bands $(37.178-33.312$ $\mathrm{KDa}$ ) were observed in the control and treated samples in the two tested grape rootstocks Salt creek and Freedom and absent in the other two tested rootstocks Dogridge and Richter.

Meanwhile, for Freedom grape rootstock, the results showed that one protein band was presented in the control at (49.447 KDa) while it was absent in the other three rootstocks. At the same time, three specific bands $(55.524-47.236-26.541 \mathrm{KDa})$ were detected in the salt stress treatments. The results demonstrated a variation as a result of salinity stress treatments might be useful in selecting grape rootstocks breeding programs. Past results can be used in establishing the fingerprint to distinguish between the cultivars and also between the treatments for the same cultivar.

\section{Isozymes electrophoresis:}

The isozymes banding pattern of peroxidase isozyme of the four rootstocks (the control and salinity stress treatments) are presented in Fig.4 and Table (4). The peroxidase patterns exhibited a total number of 7 bands in each rootstock, three $(\mathrm{Px})$ monomorphic bands $(\mathrm{Rf}=0.077-0.138-0.757)$ in control and salinity stress. On the other hand, one specific band at $\mathrm{Rf}=0.946$ found in the four treated rootstocks and not found in their control.

Table 4. Isomers of peroxidase (0 /1) and their RF value of the Grapes Salt creek, Dogridge, Richter and Freedom rootstocks.

\begin{tabular}{|c|c|c|c|c|c|c|c|c|c|}
\hline \multirow{2}{*}{$\begin{array}{c}\text { Band } \\
\text { number }\end{array}$} & \multirow{2}{*}{ RF } & \multicolumn{2}{|c|}{ Salt creek } & \multicolumn{2}{|c|}{ Dogridge } & \multicolumn{2}{|c|}{ Richter } & \multicolumn{2}{|c|}{ Freedom } \\
\hline & & Control & $100 \mathrm{mM}$ & Control & $100 \mathrm{mM}$ & Control & $100 \mathrm{mM}$ & Control & $100 \mathrm{mM}$ \\
\hline \multicolumn{10}{|c|}{ Data For peroxidase Gel Image } \\
\hline 1 & 0.077 & 1 & 1 & 1 & 1 & 1 & 1 & 1 & 1 \\
\hline 2 & 0.138 & 1 & 1 & 1 & 1 & 1 & 1 & 1 & 1 \\
\hline 3 & 0.702 & 0 & 0 & 1 & 1 & 1 & 1 & 1 & 1 \\
\hline 4 & 0.757 & 1 & 1 & 1 & 1 & 1 & 1 & 1 & 1 \\
\hline 5 & 0.813 & 1 & 1 & 0 & 1 & 1 & 1 & 0 & 1 \\
\hline 6 & 0.862 & 0 & 0 & 0 & 1 & 0 & 1 & 0 & 1 \\
\hline 7 & 0.946 & 0 & 1 & 0 & 1 & 0 & 1 & 0 & 1 \\
\hline \multicolumn{2}{|c|}{ Polymorphism\% } & \multicolumn{8}{|c|}{$57.143 \%$} \\
\hline
\end{tabular}

$\mathbf{R f}=$ Relative mobility $\quad 1=$ Present $\quad 0=$ Absent


The results showed that there was one band $(\mathrm{Rf}=$ 0.813 ) existed in salinity stressed sample of the four tested grape rootstocks. Meanwhile, control and salinity stressed samples of Dog ridge, Richter, and Freedom rootstocks recorded one band $(\mathrm{Rf}=0.702)$ while absent in the Salt creek rootstock (control and salinity stress treatment).

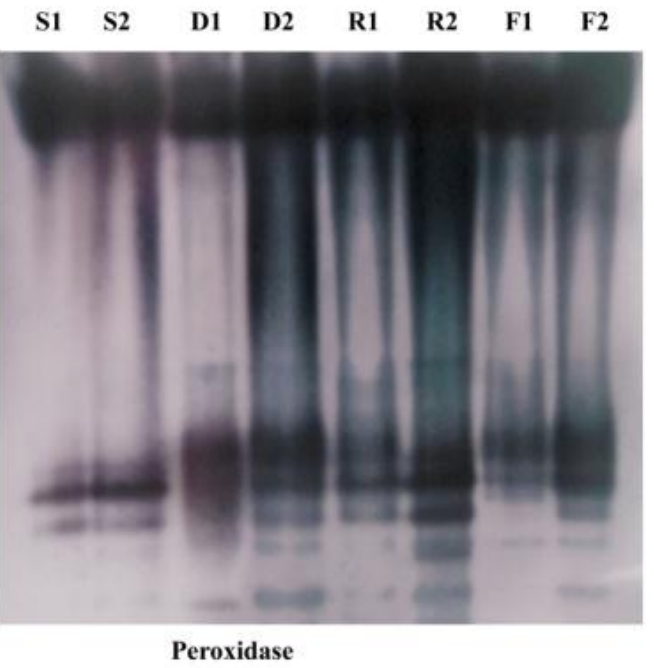

Fig (4). Zymogram peroxidase of Salt creek, Dogridge, Richter and Freedom rootstocks.

The high stability of protein profile makes protein electrophoresis a powerful tool in elucidating the origin and the evolution of cultivated plants as isozyme analysis has proved useful to identify differences in $3 \mathrm{D}$ in various organs of the same plant or to differentiate between closely related cultivars Ben-Hayyim et al., (1982).

\section{References}

Alizadeh, M., and Singh, S. 2009. Molecular Assessment of Clonal Fidelity in Micropropagated Grape (Vitis spp.) Rootstock Genotypes Using RAPD and ISSR Markers. Iranian Journal of Biotechnology, 7(1), 37-44.

Ben-Hayyim, G., Shani, A., and Vardi, A. 1982. Evaluation of isozyme systems in Citrus to facilitate identification of fusion products. Theoretical and Applied Genetics,64(1), 1-5. doi:10.1007/bf00303641

Brown, A. 1978. Isozymes, plant population genetic structure and genetic conservation. Theoretical and Applied Genetics,52(4). doi:10.1007/bf00282571

El-Sharabasy, S. F., Wanas, W. H., and Al-Kerdany, A. Y. 2008. Date palm cultivars in vitro screening to drought tolerance using isozymes. Arab Journal of Biotechnology,11(2), 263-272.

Goulão, L. and Oliveira, C.M. 2001. Molecular characterisation of cultivars of apple (Malus $\times$ domestica Borkh.) using microsatellite (SSR and ISSR) markers. Euphytica122(81) doi:10.1023/A:1012691814643.
Herrera, R., Cares, V., Wilkinson, M. J., and Caligari, P. D. S. 2002. Characterisation of genetic variation between Vitis vinifera cultivars from central Chile using RAPD and Inter Simple Sequence Repeat markers. Euphytica, 124(1), 139-145. doi:10.1023/A:1015693721532

Johnson, R.C., and Hodgkin, T. 1999 . Core collections for today and tomorrow. International Plant Genetic Resources Institute, Rome, Italy. ISBN 92-9043-424-4

Khan, A., Rabbani, M., Siddique, M., and Islam, M. 2010. Studies on the genetic diversity of pointed gourd using biochemical methods (Isozyme analysis). Bangladesh Journal of Agricultural Research,34(1). doi:10.3329/bjar.v34i1.5762

Laemmli, U. K. 1970. Cleavage of Structural Proteins during the Assembly of the Head of Bacteriophage T4. Nature,227(5259), 680-685. doi:10.1038/227680a0

Lanham, P. G., and Brennan, R. M. 1998. Characterization of the genetic resources of redcurrant (Ribes rubrum: subg. Ribesia) using anchored microsatellite markers. TAG Theoretical and Applied Genetics,96(6-7), 917-921. doi:10.1007/s001220050820

Monte-Corvo, L., Goulão, L., and Oliveira, C. 2001. ISSR Analysis of Cultivars of Pear and Suitability of Molecular Markers for Clone Discrimination. Journal of the American Society for Horticultural Science, 126(5), 517-522.

Moreno, S., Martín, J.P. and Ortiz, J.M. 1998. Intersimple sequence repeats PCR for characterization of closely related grapevine germplasm. Euphytica, 101(1), 117-125 doi.org/10.1023/A:1018379805873

Neveen, A.H., El-Homosany, A., Amina, H.G., and Mohamed, A.S. 2011 . Morphological and Issr Polymorphisms in Some Egyptian Grapes (Vitis vinefera L.) Collection. World Appl. Sci. J., 15 (10): 1369-1375.

Potter, D., Gao, F., Aiello, G., Leslie, C., and McGranahan, G. 2002. Intersimple Sequence Repeat Markers for Fingerprinting and Determining Genetic Relationships of Walnut (Juglans regia) Cultivars. Journal of the American Society for Horticultural Science, 127(1), 75-81.

Roose, M.L., Feng, D., Cheng, F.S., Tayyar, R.I., Federici, C.T. and Kupper, R.S. 2000. MAPPING THE CITRUS GENOME. Acta Hortic. 535, 2532. doi: 10.17660/ActaHortic.2000.535.1

Sankar, A. A., and Moore, G. A. 2001. Evaluation of inter-simple sequence repeat analysis for mapping in Citrus and extension of the genetic linkage map. TAG Theoretical and Applied Genetics,102(2-3), 206-214. doi:10.1007/s001220051637

Seyedimoradi, H., Talebi, R., Hassani, D., and Karami, F. 2012. Comparative genetic diversity analysis in Iranian local grapevine cultivars using ISSR and DAMD molecular markers. 
Environmental and Experimental Biology,10: 125-132.

Shiraishi, M., Fujishima, H., and Chijiwa, H. 2009. Evaluation of table grape genetic resources for sugar, organic acid, and amino acid composition of berries. Euphytica,174(1), 1-13. doi:10.1007/s10681-009-0084-4

Sokal, R. R. 1963 The Principles and Practice of Numerical Taxonomy. International Association for Plant Taxonomy (IAPT),12(5), 190-199. doi:10.2307/1217562

Stegemann, H., Afify, A. E., and Hussein, R. 1986. Identification of date (Phoenix dactylifera) cultivars by protein patterns. Phytochemistry,26(1), 149-153. doi:10.1016/s0031-9422(00)81500-9

Studier, F. 1973. Analysis of bacteriophage T7 early RNAs and proteins on slab gels. Journal of Molecular Biology,79(2), 237-248. doi:10.1016/0022-2836(73)90003-X

Tamhankar, S.A., Argade, N.C., More, M.N., Dhanorkar, V.M., Patil, S.G., Rao, V.S., Karibasappa, G.S. and Agrawal, D.C. 2008. DNA
PROFILING OF THE GRAPE VARIETIES GROWN IN INDIA USING ISSR MARKERS. Acta Horticulturae, (785), 147-152. doi: 10.17660/ActaHortic.2008.785.17

Teixeira, A., Eiras-Dias, J., Castellarin, S., and Gerós, H. 2013. Berry Phenolics of Grapevine under Challenging Environments. International Journal of Molecular Sciences, 14(12), 18711-18739. doi:10.3390/ijms140918711

Wu, Z., Fang, L., Wang, J., and Shen, Y. 2009. Analysis of Genetic Diversity Of Vitis By Using Issr Markers. Acta Horticulturae, (827), 125-130. doi:10.17660/actahortic.2009.827.17

Zeinali, R., Rahmani, F., Abaspour, N., and Baneh, H. D. 2012. Molecular and Morphological Diversity among Grapevine (Vitis Vinifera L.) Cultivars in IRAN. International Journal of Agriculture: Research and Review,2(6), 735-743

Zietkiewicz, E., Rafalski, A., and Labuda, D. 1994. Genome Fingerprinting by Simple Sequence Repeat (SSR)-Anchored Polymerase Chain Reaction Amplification. Genomics,20(2), 176183. doi:10.1006/geno.1994.1151. 
